\title{
Characterisation of microbial communities colonising the hyphal surfaces of arbuscular mycorrhizal fungi
}

\author{
Tanja R Scheublin ${ }^{1,2}$, Ian R Sanders ${ }^{1}$, Christoph Keel ${ }^{2}$ and Jan Roelof van der Meer $^{2}$ \\ ${ }^{1}$ Department of Ecology and Evolution, University of Lausanne, Lausanne, Switzerland and ${ }^{2}$ Department \\ of Fundamental Microbiology, University of Lausanne, Lausanne, Switzerland
}

\begin{abstract}
Arbuscular mycorrhizal fungi (AMF) are symbiotic soil fungi that are intimately associated with the roots of the majority of land plants. They colonise the interior of the roots and the hyphae extend into the soil. It is well known that bacterial colonisation of the rhizosphere can be crucial for many pathogenic as well as symbiotic plant-microbe interactions. However, although bacteria colonising the extraradical AMF hyphae (the hyphosphere) might be equally important for AMF symbiosis, little is known regarding which bacterial species would colonise AMF hyphae. In this study, we investigated which bacterial communities might be associated with AMF hyphae. As bacterialhyphal attachment is extremely difficult to study in situ, we designed a system to grow AMF hyphae of Glomus intraradices and Glomus proliferum and studied which bacteria separated from an agricultural soil specifically attach to the hyphae. Characterisation of attached and non-attached bacterial communities was performed using terminal restriction fragment length polymorphism and clone library sequencing of 165 ribosomal RNA (rRNA) gene fragments. For all experiments, the composition of hyphal attached bacterial communities was different from the non-attached communities, and was also different from bacterial communities that had attached to glass wool (a non-living substratum). Analysis of amplified 16S rRNA genes indicated that in particular bacteria from the family of Oxalobacteraceae were highly abundant on AMF hyphae, suggesting that they may have developed specific interactions with the fungi.
\end{abstract}

The ISME Journal (2010) 4, 752-763; doi:10.1038/ismej.2010.5; published online 11 February 2010

Subject Category: microbial population and community ecology

Keywords: arbuscular mycorrhizal fungi; bacterial community; hyphae; plant-microbe interactions; rhizosphere; T-RFLP

\section{Introduction}

Arbuscular mycorrhizal fungi (AMF) are obligate plant symbionts that are able to colonise the roots of approximately two-thirds of all terrestrial plant species (Trappe, 1987; Smith and Read, 1997). AMF can have large effects on plant growth by nutrient acquisition and protection against pathogens or drought (Davies et al., 1993; Newsham et al., 1995; Borowicz, 2001). They are intimately associated with plant roots, colonising the root cortex as well as the surrounding soil. AMF hyphae are sometimes considered as an extension of the root system, taking up (immobile) nutrients such as phosphorus from that part of the soil space that is not accessed by the plant's roots. It is well known that bacterial colonisation of the rhizosphere can be crucial for many pathogenic as well as symbiotic

Correspondence: TR Scheublin, Department of Microbial Ecology, Netherlands Institute of Ecology (NIOO-KNAW), Boterhoeksestraat 48, 6666 GA Heteren, The Netherlands.

E-mail: t.scheublin@nioo.knaw.nl

Received 27 October 2009; revised 4 January 2010; accepted 6 January 2010; published online 11 February 2010 plant-microbe interactions (Whipps, 2001; Weller, 2007). However, although extensive literature exists on rhizosphere colonisation, little is known regarding bacterial colonisation of AMF hyphae (the 'hyphosphere').

Those studies that have examined bacterial colonisation of AMF hyphae have revealed a number of important findings. First, pure cultures of a number of biocontrol, Rhizobium and soil bacteria (for example, Pseudomonas fluorescens, Rhizobium leguminosarum, Paenibacillus brasilensis, Paenibacillus peoriae and Bacillus cereus) are able to attach to AMF hyphae and differences in bacterial attachment have been found between vital and nonvital hyphae (Bianciotto et al., 1996, 2001; Toljander et al., 2006). This suggests that specific AMFbacteria interactions may exist. Second, AMF hyphae seem to influence the composition of bacterial communities in their surroundings. For example, Andrade et al. (1998) observed an increase in fluorescent pseudomonads and an Alcaligenes eutrophus strain in the presence of AMF hyphae, while Ravnskov et al. (1999) found a decrease in Pseudomonas fluorescens strain DF57. In addition, 
several studies found evidence that the bacterial community composition in soil is different in the presence or absence of AMF hyphae (MansfeldGiese et al., 2002; Marschner and Baumann, 2003; Rillig et al., 2006). Like plant roots, also AMF hyphae produce exudates and these exudates might explain the observed differences in soil bacterial communities. It has been found that extracted AMF hyphal exudates can stimulate bacterial growth (Filion et al., 1999) and change the bacterial community composition (Toljander et al., 2007).

One reason for the limited amount of information on hyphal colonisation by bacteria is that the hyphosphere is an environment, which is much more difficult to experimentally access than the rhizosphere. To analyse the rhizosphere, researchers generally take the soil adhering to roots. Unfortunately, the same approach is not feasible for the hyphosphere, because hyphae are too small and not sufficiently rigid to extract with adhering soil. Some researchers, therefore, have taken the total soil volume colonised by hyphae as the hyphosphere. In this approach there is no distinction between hyphosphere and bulk soil, and therefore it is likely to yield non-hyphosphere bacteria. Others have limited their studies to those bacterial cells directly attached to hyphae. However, although attachment to hyphae per definition means being in the hyphosphere, it is unlikely that hyphal influence would not go beyond attached cells, for example by leaked nutrients. Therefore, this approach seems too narrow. At the moment there is no solution for this problem and one has to choose between one of these non-optimal approaches.

The potential effect of bacterial hyphal colonisers on AMF and the AMF symbiosis is high. Several types of interactions between bacteria and AMF have been described (Bonfante and Anca, 2009). So-called mycorrhiza helper bacteria have been shown to promote mycelial growth and mycorrhiza formation (Garbaye, 1994; Frey-Klett et al., 2007). Several studies have reported interactive effects between plant-growth-promoting bacteria, pathogens, rhizobia and AMF (Azcon-Aguilar and Barea, 1996; Requena et al., 1997; Xavier and Germida, 2002; Wamberg et al., 2003). Moreover, bacteria have been isolated from AMF spores and mycorrhizal cultures that promote or sometimes inhibit AMF spore germination, mycorrhisation and plant growth (Mayo et al., 1986; Budi et al., 1999; Xavier and Germida, 2003). Such data suggest that bacterial colonisers of AMF hyphae may have an important role for successful AMF plant colonisation and symbiosis. As a result of the tight association between AMF and plants, and the importance for plant ecology and (sustainable) agriculture (Johansson et al., 2004), further insights into bacteria-AMF interactions are highly relevant.

The main goals of this project were to investigate colonisation of the AMF hyphal surface by bacteria, to determine whether attachment is specific, to identify possible main hyphal colonisers, and to study consequent changes in bacterial community composition after being in contact with AMF hyphae. The approach we take in this study is to use in vitro cultures of the AMF Glomus intraradices and Glomus proliferum, grown in compartmented plates in which the hyphae can be brought into contact with total bacterial communities extracted from agricultural soils. Microscopy and molecular community analysis methods based on amplified 16S ribosomal RNA (rRNA) gene diversity were then used to analyse specific attachment. To our knowledge this is the first study to take such an in vitro community approach to investigate bacterial attachment to AMF hyphae.

\section{Materials and methods}

\section{Fungal isolates and preparation of soil bacterial suspension}

We used four different AMF isolates, three isolates of the species $G$. intraradices, namely DAOM 181602 (Biosystematics Research Centre, Ottawa, Canada), C2 and C3 (Koch et al., 2004), and one G. proliferum isolate, MUCL 41827 (Declerck et al., 2000). Bacterial communities were isolated from top soil $(0-10 \mathrm{~cm})$ collected at an agricultural field on the campus of the University of Lausanne (claymineral dominated Cambisol, pH 5, see Supplementary methods for analysis of the soil composition). Ten grams of fresh soil was mixed with $40 \mathrm{ml}$ of $0.1 \% \mathrm{Na}_{4} \mathrm{P}_{2} \mathrm{O}_{7}(\mathrm{pH}$ 7) in a blender (A11 basic, IKAWerke, Staufen, Germany), for four times during $7 \mathrm{~s}$, with $2 \mathrm{~min}$ intervals on ice. The suspension was centrifuged for $5 \mathrm{~min}$ at $150 \times \mathrm{g}$ and $4{ }^{\circ} \mathrm{C}$ to precipitate soil particles. The supernatant was filtered through a $30-\mu \mathrm{m}$ sieve, and $5 \mathrm{ml}$ of Nycodenz (Optiprep, Axis-Shield, Oslo, Norway) was pipetted below the aqueous phase filtrate. After centrifugation for $20 \mathrm{~min}$ at $3000 \times g$ and $4{ }^{\circ} \mathrm{C}, 5 \mathrm{ml}$ of the interphase containing the bacteria was collected and diluted with $5 \mathrm{ml}$ of $0.1 \% \mathrm{Na}_{4} \mathrm{P}_{2} \mathrm{O}_{7}$. A second Nycodenz centrifugation step was performed for $60 \mathrm{~min}$ at $3000 \times \mathrm{g}$ and $4{ }^{\circ} \mathrm{C}$. In all, $3 \mathrm{ml}$ of the interphase was diluted with $9 \mathrm{ml}$ of liquid M-medium without sucrose (Becard and Fortin, 1988; $3 \mathrm{mM} \mathrm{MgSO}_{4}, 0.79 \mathrm{mM} \mathrm{KNO}_{3}, 0.87 \mathrm{mM} \mathrm{KCl}$, $35 \mu \mathrm{M} \mathrm{KH} \mathrm{KO}_{4}, 1.2 \mathrm{mM} \mathrm{Ca}\left(\mathrm{NO}_{3}\right)_{2}, 20 \mu \mathrm{M} \mathrm{Fe}(\mathrm{Na})$ EDTA, $4.5 \mu \mathrm{M} \mathrm{KI}, 30 \mu \mathrm{M} \mathrm{MnCl}_{2}, 9.2 \mu \mathrm{M} \mathrm{ZnSO}_{4}, 24 \mu \mathrm{M} \mathrm{H}_{3} \mathrm{BO}_{3}$, $0.52 \mu \mathrm{M} \mathrm{CuSO}_{4}, 9.9 \mu \mathrm{M} \mathrm{Na}_{2} \mathrm{MoO}_{4}$, Gamborg's vitamin solution (Sigma, St Louis, MO, USA)). After centrifugation for $15 \mathrm{~min}$ at $3000 \times \mathrm{g}$, the pellet was resuspended in $3 \mathrm{ml}$ of liquid M-medium without sucrose.

\section{Attachment assays}

AMF isolates were grown on Root tumor-inducing plasmid T-DNA-transformed Daucus carota roots in two-compartment plates, which consist of a root compartment with AMF-colonised carrot roots and 
a hyphal compartment without roots (St-Arnaud et al., 1996). When AMF hyphae started to grow in the hyphal compartment (after 46-75 days), a block of $2 \times 5 \mathrm{~cm}$ was removed from the hyphal compartment and replaced with liquid M-medium without sucrose. After another 9-26 days, when hyphae visibly colonised the liquid compartment, $200 \mu \mathrm{l}$ of soil bacterial suspension (see above) was added. Bacterial suspensions were always freshly prepared and inoculated directly after isolation. Hyphae and bacteria were incubated for $20 \mathrm{~h}$ at $25^{\circ} \mathrm{C}$. This period allows good attachment of bacteria to the hyphae, but is short enough to prevent other fungi (that is, contaminants introduced with the bacterial inoculum) to establish. Hyphae with attached bacteria were removed from the compartment using a flamesterilised forceps and washed in liquid M-medium without sucrose. The rest of the liquid medium (approximately $4 \mathrm{ml}$ ) was collected and centrifuged for $15 \mathrm{~min}$ at $15000 \times \mathrm{g}$ to collect the remaining bacteria. Bacterial pellets and hyphae with attached bacteria were stored separately at $-20^{\circ} \mathrm{C}$ until DNA isolation, or fixed in ethanol for microscopic observation. In one experiment, the total number of bacteria and their vitality was determined at the time of inoculation and after the 20-h incubation. Cells were stained with LIVE/DEAD BacLight Bacterial Vitality Kit (Invitrogen, Carlsbad, CA, USA), and life and dead cells were counted in a Thoma chamber under an epifluorescent microscope (Axioskops 2, Zeiss, Jena, Germany).

A total of three attachment experiments were carried out. In the first experiment (experiment A), we used six replicate plates of $G$. intraradices isolate C3. The C3 isolate produces relatively high amounts of hyphae. A negative control without added bacteria was included in this experiment. In the second experiment (experiment $\mathrm{B}$ ), we used four different AMF isolates, with nine replicate plates for isolate $\mathrm{C} 3$, five replications for isolate $\mathrm{C} 2$, seven for isolate DAOM 181602 and four for G. proliferum. The number of replications in experiment $B$ is unequal because many plates failed to produce sufficient hyphal material in the liquid compartment. In the third experiment (experiment C), we compared bacterial attachment to AMF hyphae with attachment to glass wool as a non-living control substrate. Six replicate plates with isolate C3 were used and six replicate plates in which sterile glass wool was added to the liquid compartment (that is, these plates were not inoculated with AMF, and therefore the liquid compartment did not contain hyphae).

\section{Microscopic observation of bacterial attachment to hyphae}

Sub-samples of the collected hyphae and bacteria were fixed in ethanol and stained with $1 \mu \mathrm{g}$ per ml 4',6-diamidino-2-phenylindole (DAPI) for $15 \mathrm{~min}$ in the dark. Hyphae were mounted on a microscope slide and observed under an epifluorescent microscope (Axioskops 2, Zeiss) with blue filter (Excision $385 \mathrm{~nm}$, beam splitter $395 \mathrm{~nm}$, emission long pass $420 \mathrm{~nm})$.

\section{DNA isolation and terminal restriction fragment} length polymorphism ( $T$-RFLP)

DNA from hyphae plus bacteria, or soil bacteria alone was isolated by a bead-beating procedure according to the protocol described by Bürgmann et al. (2001) with small modifications. A PCR was performed with the general bacterial primers 27f (5'-AGAGTTTGATCCTGGCTCAG-3'; Lane, 1991) and 1492r (5'-GGTTACCTTGTTACGACTT-3'; Lane, 1991), of which primer $27 \mathrm{f}$ was labelled with hexachloro-6-carboxyfluorescein. After purification, a quantity of $500 \mathrm{ng}$ of PCR product was digested with HaeIII. T-RFLP community profiles were determined with $1 \mu \mathrm{l}$ of digested product on an ABI 3100 Genetic Analyser (Applied Biosystems, Foster City, CA, USA). A detailed description of the DNA isolation procedure and T-RFLP analysis is found in the Supplementary methods.

\section{Clone libraries}

DNA isolated from experiment $\mathrm{B}$ was used to construct eight clone libraries, one for the bacterial fraction attached to hyphae and one for the nonattaching bacterial fraction, times four for the four different AMF isolates. DNA obtained from replicate plates was mixed in equal amounts and 16S rRNA gene fragments were amplified in a PCR using primers $27 \mathrm{f}$ and 534r (5'-ATTACCGCGGCTGCTGG-3'; Muyzer et al., 1993). PCR fragments were ligated into pGEM-T Easy (Promega, Madison, WI, USA) and transformed into competent Escherichia coli DH5 $\alpha$ cells (OneShot MaxEfficiency; Invitrogen). Using plasmid-specific primer T7, 48 clones were sequenced for each library, resulting in a total of 384 sequenced clones (see Supplementary methods for a detailed description of the cloning and sequencing procedure). Sequences were deposited in GenBank under accession numbers GQ403990 to GQ404373.

\section{Analysis}

T-RFLP profiles were analysed using the ABI GENEMAPPER software, version 3.7 (Applied Biosystems). Bins were automatically created using the automatic panel generation feature and then manually corrected. Total peak height of the T-RFLP profiles was at least 3000 relative fluorescent units and peaks smaller than $1 \%$ of the total peak height were removed from the analysis.

Statistical analyses were performed using the $\mathrm{R}$ software (http://www.r-project.org/). The community profiles were analysed by correspondence analysis ( $R$ function 'cca (vegan)'). The relative 
abundance of individual terminal restriction fragments (T-RFs) between samples was compared using a paired $t$-test ( $\mathrm{R}$ function 't.test (stats)'). Separate tests were performed for each T-RF. As multiple testing increases the chance to find significant results, the significance levels are separately shown for $0.01<P<0.05,0.001<P<0.01$ and $P<0.001$.

Sequences from the clone library were operationally assigned a taxonomic position in the Ribosomal Database Project (release 9, https://rdp.cme.msu. edu/index.jsp) using the CLASSIFIER option with a confidence threshold of $80 \%$ (Wang et al., 2007). A theoretical digest with HaeIII was performed for all sequences and the size of the terminal fragment was calculated. This, we called the predicted T-RF size. One to four representative plasmid clones of each predicted T-RF size and each operational taxonomic unit (OTU) were reanalysed for apparent T-RF size on the ABI sequencer. This allowed us to match the TRFs in the community T-RFLP electropherograms to the corresponding OTUs from the clone library.

\section{Results}

To analyse bacterial colonisation of AMF hyphae, we developed an experimental system in which soil bacteria that were separated from soil particles could be incubated with axenically pre-grown AMF hyphae in liquid compartments. Microscopic observation of AMF hyphae from our experimental system confirmed bacterial attachment to the hyphae. This was most easily observed on samples stained with DAPI (Figure 1). In some cases, only few bacterial cells were found to be attached to the hyphae, whereas in other cases hyphae were covered almost completely with bacteria or with microcolonies of cells (Figure 1). At the time of inoculation the liquid compartment contained $3.3 \times 10^{6}$ bacteria per ml with $86 \%$ vital cells. After 20 -h incubation, these numbers increased to $1.76 \times 10^{7} \pm 0.13 \times 10^{7}$ bacteria per ml (average \pm s.d.) with $91 \pm 1 \%$ vitality.

Bacterial communities sticking to AMF hyphae were examined by T-RFLP analysis and compared
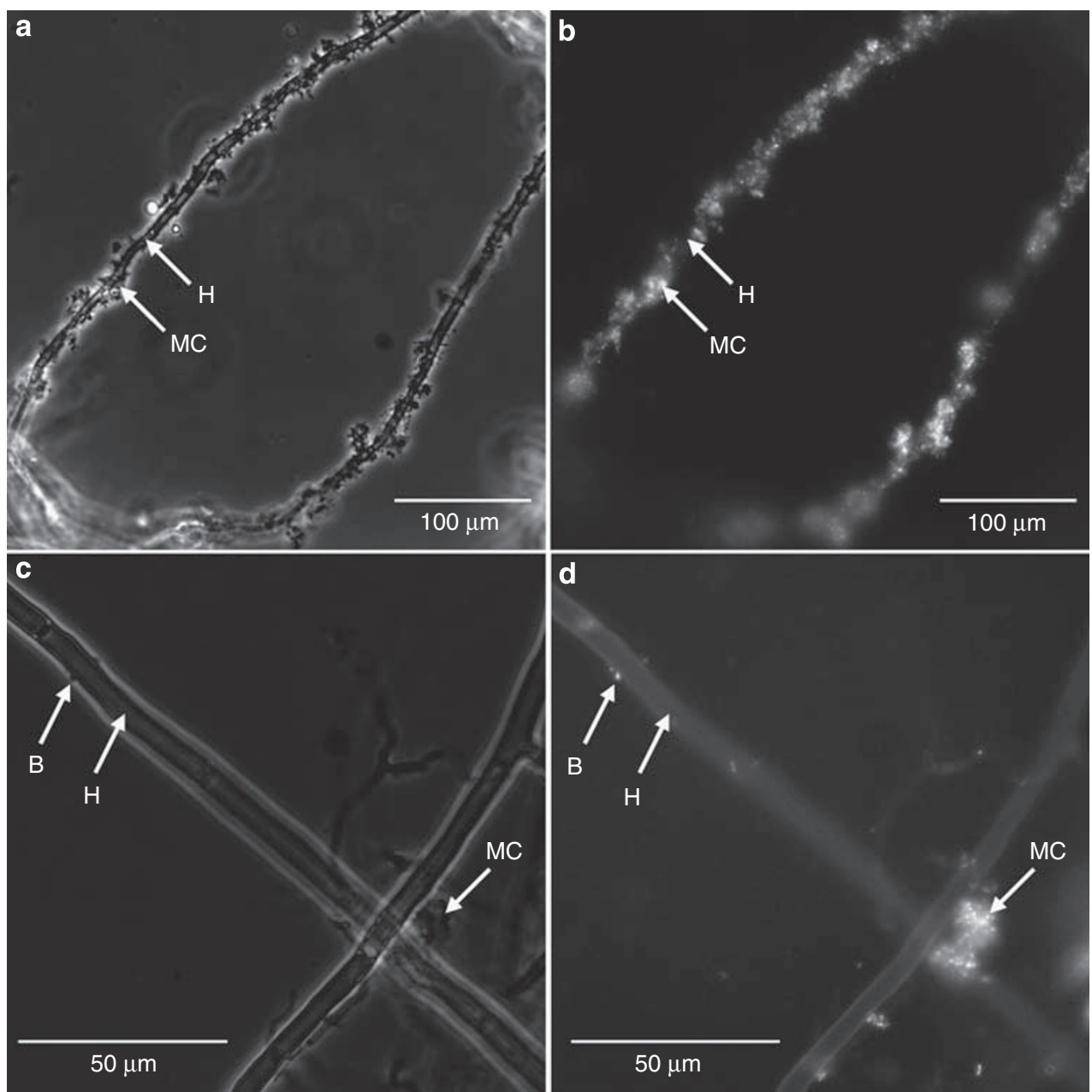

Figure 1 DAPI-stained AMF hyphae with attached soil bacteria. Pictures were taken with normal light (a, c) or fluorescence (b, d); H, hyphae; B, bacteria; MC, microcolony of bacteria. Hyphae in pictures a/b are densely colonised with bacteria, while pictures $\mathrm{c} / \mathrm{d}$ show attachment of single bacteria and a microcolony. 
with the community composition of bacteria remaining in solution. Three independent experiments were carried out with each time freshly isolated soil bacteria. All three showed a clear overall distinction between the T-RFLP profiles produced from bacteria that had attached to AMF hyphae and those that had remained in solution (Figures 2a-c). No significant differences were found between the T-RFLP profiles of bacterial communities attaching to hyphae of different AMF isolates (Figure 2b). T-RFLPs produced from attached bacterial communities also differed between AMF hyphae and glass wool as a non-living control substrate (Figure 2c). In this experiment, the communities that remained in solution were also different between compartments containing hyphae or glass wool. The negative control without bacteria did not result in a PCR product and the T-RFLP profile revealed no peaks, neither for DNA isolated from hyphae alone, nor from the AMF growth medium without bacteria added.

A comparison of the relative abundances of individual T-RFs showed that 6-8 T-RFs were more abundant in hyphae-attached communities than in non-attached communities, whereas 7-16 T-RFs were less abundant (Figure 3 and Supplementary Figure 1). To analyse which bacterial groups were represented by those T-RFs, we constructed clone libraries from the DNA of experiment B. A total of 384 clones were sequenced. Table 1 shows the operational taxonomic assignment of the clones and the number of assigned clones in each library.

As differences can occur between the size of a theoretical digest (predicted size) and the apparent T-RF size obtained from the capillary sequencer, we determined the T-RF sizes on cloned fragments in the library for one to four representatives of each fragment size and each OTU. The difference between the apparent T-RF size and the predicted size was usually between 1 and $2 \mathrm{bp}$, but could amount to $6 \mathrm{bp}$, in particular for the smaller-sized T-RFs (Table 2). We also observed that fragments of the same predicted size but from different OTUs could result in different apparent T-RF sizes in the electropherogram. For example, a predicted T-RF of $217 \mathrm{bp}$ was found to produce T-RFs of 213, 215 and $216 \mathrm{bp}$ for clone inserts from different OTUs (Table 2). Overall, the clone library contained 32 OTUs for 40 apparent T-RF sizes. Some OTUs were presented by several T-RFs whereas most T-RFs represented more than one OTU.

Many T-RFs were represented by one dominant OTU that could be identified up to the genus level. For example, T-RFs of 73, 197, 198, 216, 218 and $401 \mathrm{bp}$ were deduced to represent members of the Oxalobacteraceae family (Duganella, Janthinobacterium, Massilia and unclassified Oxalobacteraceae). These T-RFs were generally more abundant in the T-RFLP profiles from hyphae-attached communities, except for T-RF 198. T-RFs 222 and 223, which represent Streptomyces spp., were also more
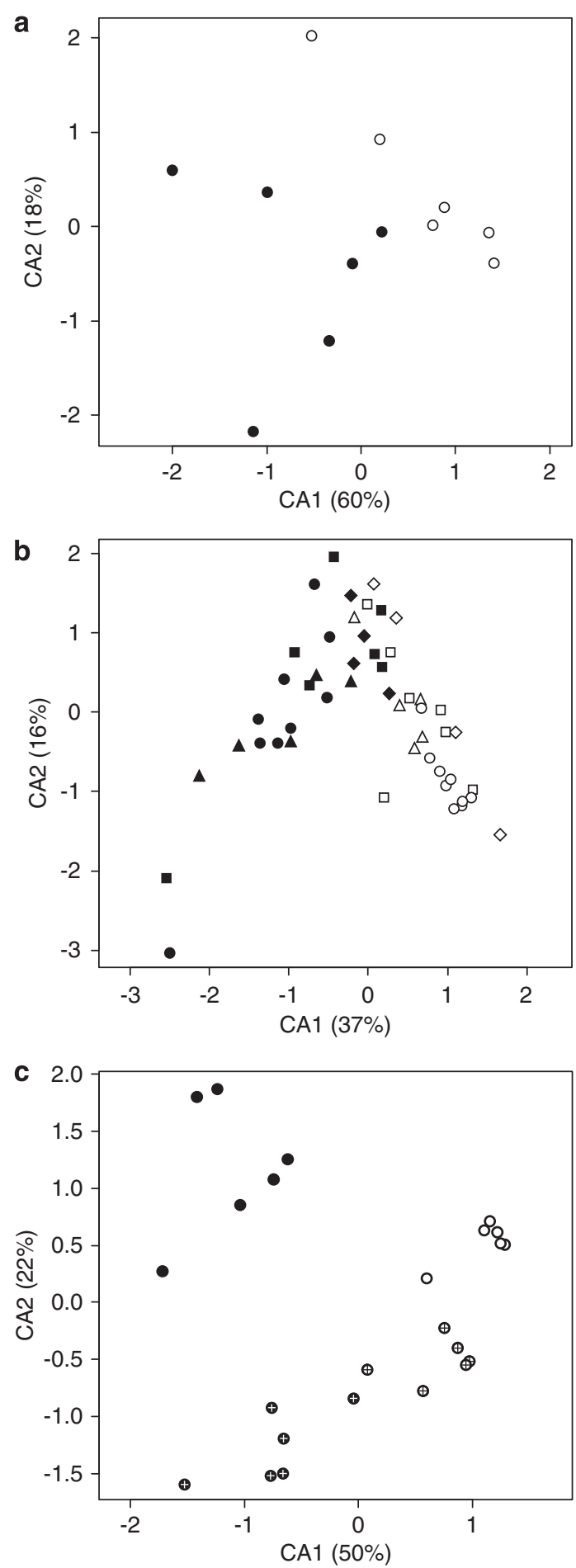

Figure 2 Correspondence analysis (CA) of the bacterial community composition identified by T-RFLP. Relative abundance data of T-RFs were used for CA analysis and the first two dimensions were plotted, (a) experiment A, comparing hyphae-attached and non-attached communities, (b) experiment B, comparing attachment between different AMF isolates and (c) experiment $\mathrm{C}$, comparing attachment to AMF hyphae and glasswool. Black symbols, non-attached communities; white symbols, hyphaeattached communities; circle, G. intraradices strain C3; triangle, $G$. intraradices strain C2; square, G. intraradices strain DAOM 181602; diamond, G. proliferum strain MUCL 41827; crossed circles, glass wool. Shown in brackets is the percentage of variance explained by that axis. 
Table 1 Number of clones per operational taxonomic unit from each library

\begin{tabular}{|c|c|c|c|c|c|c|c|c|c|}
\hline \multirow[t]{2}{*}{ Operational taxonomic unit } & \multicolumn{4}{|c|}{ Non-attaching communities } & \multicolumn{4}{|c|}{ Attaching communitites } & \multirow[t]{2}{*}{ Total } \\
\hline & C2 & C3 & $D$ & $M$ & C2 & C3 & $D$ & $M$ & \\
\hline Bacillus & 4 & 0 & 0 & 2 & 0 & 0 & 0 & 0 & 6 \\
\hline Paenibacillus & 1 & 0 & 0 & 0 & 0 & 1 & 0 & 0 & 2 \\
\hline Caulobacter & 0 & 0 & 0 & 0 & 1 & 0 & 0 & 0 & 1 \\
\hline Methylobacterium & 0 & 0 & 0 & 0 & 1 & 0 & 0 & 0 & 1 \\
\hline Rhizobium & 0 & 1 & 0 & 0 & 0 & 0 & 0 & 0 & 1 \\
\hline Unclassified Rhizobiaceae & 0 & 0 & 0 & 0 & 0 & 0 & 1 & 0 & 1 \\
\hline Unclassified Rhizobiales & 0 & 0 & 0 & 1 & 0 & 0 & 1 & 0 & 2 \\
\hline Novosphingobium & 0 & 0 & 0 & 0 & 1 & 0 & 0 & 0 & 1 \\
\hline Sphingopyxis & 0 & 0 & 1 & 0 & 0 & 0 & 0 & 0 & 1 \\
\hline Unclassified Sphingomonadaceae & 0 & 0 & 0 & 0 & 0 & 0 & 1 & 0 & 1 \\
\hline Unclassified Alphaproteobacteria & 0 & 0 & 0 & 1 & 1 & 0 & 0 & 0 & 2 \\
\hline Duganella & 2 & 0 & 3 & 3 & 4 & 3 & 5 & 8 & 28 \\
\hline Janthinobacterium & 2 & 0 & 0 & 0 & 0 & 0 & 0 & 0 & 2 \\
\hline Massilia & 0 & 4 & 2 & 0 & 2 & 1 & 0 & 1 & 10 \\
\hline Unclassified Oxalobacteraceae & 17 & 10 & 9 & 8 & 15 & 10 & 7 & 6 & 82 \\
\hline Pelomonas & 0 & 0 & 0 & 0 & 0 & 0 & 0 & 1 & 1 \\
\hline Unclassified Incertae sedis 5 & 2 & 1 & 0 & 0 & 1 & 1 & 1 & 0 & 6 \\
\hline Ralstonia & 0 & 0 & 0 & 0 & 0 & 0 & 1 & 0 & 1 \\
\hline Polaromonas & 0 & 0 & 0 & 0 & 0 & 0 & 0 & 1 & 1 \\
\hline Rhodoferax & 0 & 0 & 0 & 0 & 0 & 0 & 0 & 1 & 1 \\
\hline Unclassified Burkholderiales & 0 & 0 & 0 & 0 & 0 & 1 & 0 & 0 & 1 \\
\hline Acinetobacter & 3 & 0 & 4 & 0 & 0 & 0 & 1 & 0 & 8 \\
\hline Pseudomonas & 7 & 10 & 18 & 12 & 15 & 5 & 19 & 22 & 108 \\
\hline Enterobacter & 0 & 1 & 1 & 4 & 1 & 6 & 0 & 0 & 13 \\
\hline Erwinia & 0 & 0 & 0 & 3 & 0 & 3 & 1 & 0 & 7 \\
\hline Serratia & 1 & 1 & 0 & 0 & 0 & 0 & 0 & 0 & 2 \\
\hline Yersinia & 0 & 0 & 0 & 0 & 0 & 1 & 0 & 0 & 1 \\
\hline Unclassified Enterobacteriaceae & 1 & 0 & 4 & 1 & 1 & 1 & 1 & 0 & 9 \\
\hline Lysobacter & 0 & 0 & 0 & 1 & 0 & 0 & 0 & 0 & 1 \\
\hline Unclassified Xanthomonadaceae & 0 & 0 & 0 & 1 & 0 & 0 & 0 & 0 & 1 \\
\hline Streptomyces & 4 & 18 & 3 & 7 & 3 & 10 & 8 & 6 & 59 \\
\hline Cellulomonas & 0 & 0 & 0 & 0 & 0 & 0 & 1 & 0 & 1 \\
\hline Arthrobacter & 0 & 0 & 2 & 0 & 0 & 2 & 0 & 0 & 4 \\
\hline Rhodococcus & 0 & 1 & 0 & 0 & 0 & 0 & 0 & 0 & 1 \\
\hline Agromyces & 0 & 1 & 0 & 1 & 0 & 0 & 0 & 0 & 2 \\
\hline Unclassified Microbacteriaceae & 0 & 0 & 0 & 0 & 0 & 1 & 0 & 0 & 1 \\
\hline Marmoricola & 0 & 0 & 0 & 0 & 1 & 0 & 0 & 0 & 1 \\
\hline Unclassified Nocardioidaceae & 0 & 0 & 0 & 1 & 0 & 0 & 0 & 0 & 1 \\
\hline Unclassified Micromonosporaceae & 0 & 0 & 0 & 0 & 0 & 0 & 0 & 1 & 1 \\
\hline Solirubrobacter & 1 & 0 & 0 & 0 & 0 & 0 & 0 & 0 & 1 \\
\hline Unclassified Actinobacteria & 0 & 0 & 0 & 0 & 0 & 1 & 0 & 0 & 1 \\
\hline Gp3 & 0 & 0 & 0 & 0 & 0 & 0 & 0 & 1 & 1 \\
\hline Gp6 & 1 & 0 & 0 & 0 & 0 & 0 & 0 & 0 & 1 \\
\hline Flavobacterium & 2 & 0 & 0 & 0 & 0 & 0 & 0 & 0 & 2 \\
\hline Adhaeribacter & 0 & 0 & 1 & 0 & 0 & 0 & 0 & 0 & 1 \\
\hline Unclassified Planctomycetaceae & 0 & 0 & 0 & 0 & 1 & 0 & 0 & 0 & 1 \\
\hline Unclassified Bacteria & 0 & 0 & 0 & 2 & 0 & 1 & 0 & 0 & 3 \\
\hline Total & 48 & 48 & 48 & 48 & 48 & 48 & 48 & 48 & 384 \\
\hline
\end{tabular}

C2, C3, D: Glomus intraradices isolate C2, C3 and DAOM181602, respectively; M: Glomus proliferum MUCL41827.

abundant in hyphae-attached communities. In experiment $\mathrm{C}$, this $\mathrm{T}-\mathrm{RF}$ was even completely absent from the non-attached bacterial communities and from the communities attached to glass wool (Supplementary Figure 1b). By contrast, T-RF 230 and T-RF 233, which are predicted to represent mostly Bacillus spp., were strongly decreased or absent from hyphae-attached communities. Also T-RF 255 was less abundant in hyphal-derived material across all four experiments. This T-RF is predicted to have originated from Acinetobacter spp. T-RF 33 was one of the most abundant T-RFs across all experiments and was also consistently less abundant in hyphae-attached communities. OTU assignments of this T-RF suggest that most of the DNAs originate from Pseudomonas spp., but this T-RF also contains several other OTUs. As the differences in abundance are relatively small, we cannot attribute the change in abundance of T-RF 33 to one OTU at species level. 


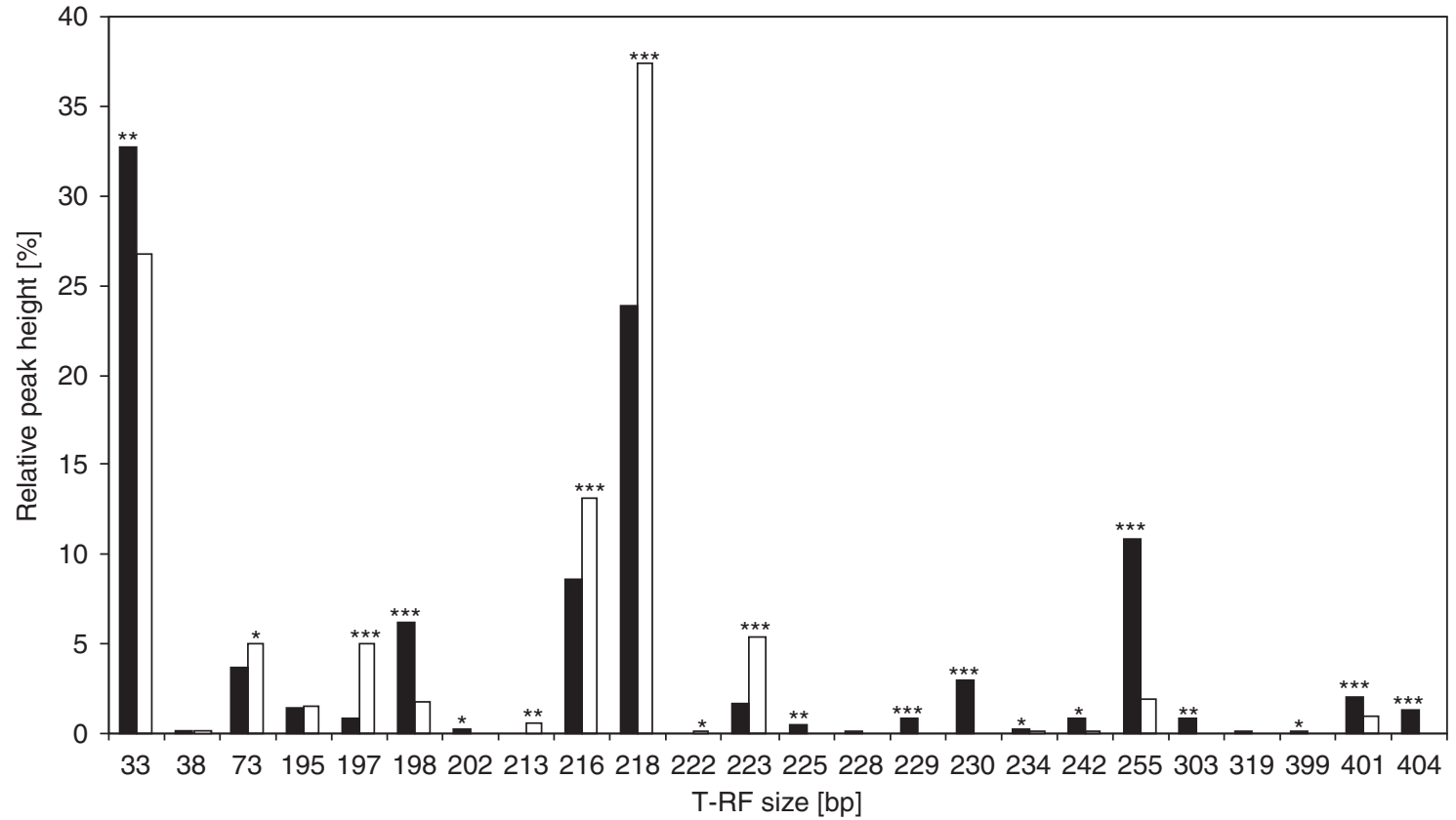

Figure 3 Relative peak heights of T-RFs from bacterial communities in experiment B. Each column represents the average peak height over all hyphae-attached or non-attached communities. Black bars, non-attached communities; white bars, hyphae-attached communities. For each T-RF a paired $t$-test was performed, ${ }^{*} 0.01<P<0.05,{ }^{* *} 0.001<P<0.01$ and ${ }^{* * *} P<0.001$.

Table 2 Comparison of T-RF sizes calculated from the DNA sequence of 16S rRNA gene fragments in the clone libraries (predicted T-RF size), with the apparent T-RF size in capillary electrophoresis

\begin{tabular}{|c|c|c|c|c|}
\hline $\begin{array}{l}\text { Apparent T-RF } \\
\text { size (bp) }\end{array}$ & $\begin{array}{l}\text { Predicted } T-R F \\
\text { size (bp) }\end{array}$ & No. clones & $\%$ & Operational taxonomic unit \\
\hline \multirow[t]{11}{*}{33} & 39 & 106 & 74 & Pseudomonas \\
\hline & & 13 & $\mathbf{9}$ & Enterobacter \\
\hline & & 7 & 5 & Erwinia \\
\hline & & 2 & 1 & Serratia \\
\hline & & 1 & 1 & Yersinia \\
\hline & & $\mathbf{9}$ & 6 & Unclassified Enterobacteriaceae \\
\hline & & 1 & 1 & Lysobacter \\
\hline & & 1 & 1 & Unclassified Xanthomonadaceae \\
\hline & & 1 & 1 & Caulobacter \\
\hline & & 1 & 1 & Solirubrobacter \\
\hline & & 1 & 1 & Adhaeribacter \\
\hline \multirow[t]{4}{*}{64} & 67 & 1 & 25 & Rhodococcus \\
\hline & & 1 & 25 & Marmoricola \\
\hline & & 1 & 25 & Unclassified Nocardioidaceae \\
\hline & & 1 & 25 & Unclassified Micromonosporaceae \\
\hline 66 & 70 & 1 & 100 & Unclassified Bacteria \\
\hline 67 & 71 & 1 & 100 & Unclassified Sphingomonadaceae \\
\hline 72 & 76 & 2 & 100 & Unclassified Alphaproteobacteria \\
\hline \multirow[t]{3}{*}{73} & 77 & 3 & 38 & Duganella \\
\hline & & 1 & 13 & Massilia \\
\hline & & 4 & $\mathbf{5 0}$ & Unclassified Oxalobacteraceae \\
\hline 159 & 163 & 1 & 100 & Unclassified Bacteria \\
\hline 163 & 165 & 1 & 100 & Methylobacterium \\
\hline 167 & 170 & 1 & 100 & Unclassified Actinobacteria \\
\hline 187 & 191 & 1 & 100 & Unclassified Rhizobiales \\
\hline \multirow[t]{2}{*}{192} & 193 & 2 & 67 & Duganella \\
\hline & 195 & 1 & 33 & Unclassified Rhizobiales \\
\hline \multirow[t]{2}{*}{ 196/197 } & 198 & 2 & 25 & Duganella \\
\hline & & $\overline{6}$ & 75 & Unclassified Oxalobacteraceae \\
\hline 197 & 199 & 1 & 100 & Unclassified Oxalobacteraceae \\
\hline \multirow{4}{*}{198} & 200 & $\mathbf{9}$ & 43 & Massilia \\
\hline & & 10 & 48 & Unclassified Oxalobacteraceae \\
\hline & & 1 & 5 & Rhodoferax \\
\hline & & 1 & 5 & Pseudomonas \\
\hline
\end{tabular}


Table 2 (Continued)

\begin{tabular}{|c|c|c|c|c|}
\hline $\begin{array}{l}\text { Apparent T-RF } \\
\text { size (bp) }\end{array}$ & $\begin{array}{l}\text { Predicted T-RF } \\
\quad \text { size }(b p)\end{array}$ & No. clones & $\%$ & Operational taxonomic unit \\
\hline 205 & 206 & 1 & 100 & Ralstonia \\
\hline 209 & 212 & 1 & 100 & Pelomonas \\
\hline 212 & 214 & 1 & 100 & Gp3 \\
\hline 213 & 217 & 2 & 100 & Unclassified Incertae sedis 5 \\
\hline 215 & 217 & 4 & 100 & Unclassified Incertae sedis 5 \\
\hline \multirow[t]{2}{*}{216} & 217 & 16 & 64 & Duganella \\
\hline & & 9 & 36 & Unclassified Oxalobacteraceae \\
\hline 217 & 218 & 1 & 100 & Unclassified Oxalobacteraceae \\
\hline \multirow[t]{4}{*}{218} & 219 & 5 & $\mathbf{9}$ & Duganella \\
\hline & & 2 & 3 & Janthinobacterium \\
\hline & & $\mathbf{5 0}$ & 86 & Unclassified Oxalobacteraceae \\
\hline & & 1 & 2 & Unclassified Burkholderiales \\
\hline 220 & 222 & 1 & 100 & Thermomicrobium \\
\hline 222 & 223 & 1 & 100 & Streptomyces \\
\hline 223 & 224 & 58 & 100 & Streptomyces \\
\hline \multirow[t]{3}{*}{224} & 224 & 1 & 33 & Unclassified Planctomycetaceae \\
\hline & 225 & 1 & 33 & Rhizobium \\
\hline & 225 & 1 & 33 & Unclassified Rhizobiaceae \\
\hline \multirow[t]{3}{*}{228} & 227 & 1 & 25 & Novosphingobium \\
\hline & 228 & 2 & 50 & Arthrobacter \\
\hline & 229 & 1 & 25 & Cellulomonas \\
\hline 229 & 230 & 1 & 100 & Unclassified Microbacteriaceae \\
\hline \multirow[t]{3}{*}{230} & 229 & 1 & 17 & Agromyces \\
\hline & 230 & 2 & 33 & Arthrobacter \\
\hline & 231 & 3 & $\mathbf{5 0}$ & Bacillus \\
\hline 231 & 230 & 1 & 100 & Agromyces \\
\hline 232 & 233 & 1 & 100 & Gp6 \\
\hline 234 & 233 & 3 & 100 & Bacillus \\
\hline 255 & 253 & 8 & 100 & Acinetobacter \\
\hline 263 & 262 & 1 & 100 & Flavobacterium \\
\hline 277 & 279 & 1 & 100 & Flavobacterium \\
\hline 291 & 293 & 1 & 100 & Sphingopyxis \\
\hline 303 & 305 & 2 & 100 & Paenibacillus \\
\hline 312 & 313 & 1 & 100 & Polaromonas \\
\hline 401 & 404 & 1 & 100 & Unclassified Oxalobacteraceae \\
\hline$>500$ & $>495$ & 1 & 100 & Pseudomonas \\
\hline
\end{tabular}

Abbreviations: rRNA, ribosomal RNA; T-RF, terminal restriction fragment.

For each apparent T-RF size, the corresponding predicted T-RF size(s) as well as the number of clones in each operational taxonomic unit (OTU) is given. The percentage of clones per OTUs is calculated for each (apparent) T-RF individually. In bold are indicated those T-RFs that were also found in the T-RFLP community profile, in regular font those that were present only in the clone library (compare with Figure 3 ). Note that not all T-RFs from the community profile were also found in the clone library.

\section{Discussion}

In this paper, we studied the types of bacteria from soil, which adhere specifically to AMF hyphae. As bacterial adherence to AMF hyphae is extremely difficult to examine in situ in the soil, we used an experimental setup in which AMF hyphae were first allowed to grow under sterile conditions. Bacteria were then freshly separated from agricultural soil samples and brought into contact with living sterile hyphae for a period of $20 \mathrm{~h}$. Our hypothesis was therefore that bacteria, which would adhere to and perhaps start to multiply on the hyphae during the period of contact, might be indicative for bacteria that interact with AMF under real soil conditions. To identify those bacteria that would adhere 'specifically' to AMF hyphae, we compared compositional differences of amplified 16S rRNA gene fragments in DNA purified from bacterial fractions that had attached to hyphae during the incubation period, and the bacterial fraction remaining in the incubation solution. Importantly, our 16S rRNA gene diversity data show that bacterial communities that adhered to AMF hyphae were significantly different from non-attaching communities. One should realise that both community samples will overlap, because they are derived from one and the same community during the incubation. The result of this is that even for species that are enriched in the attached fraction, one will likely still find them in the non-attached fraction.

We also obtained some evidence regarding the specificity of the interactions. The composition of bacterial communities attached to AMF hyphae was different from that of communities attached to glass wool during the same incubation time, but no differences were observed between communities attached to four different AMF isolates. These AMF isolates were, however, closely related, and therefore a comparison between more distantly 
related AMF species and/or other fungal species would be necessary to further elucidate the specificity of these interactions. Differences in communities attached to hyphae and glass wool suggest that not just physicochemical attraction was responsible for attachment to AMF hyphae, but that there may have been some population growth already on the hyphae during the incubation period or that there were specific signalling interactions that made certain types of bacteria attracted to the hyphae. As the communities that remained in solution were also different between compartments containing hyphae or glass wool, it is not unlikely that hyphal exudates have had a role in shaping these communities. A study by Toljander et al. (2007), using exudates isolated from AMF hyphae, have also shown a marked influence of AMF hyphal exudates on bacterial community composition. They detected several low-molecular-mass sugars and organic acids as well as some unidentified high-molecularmass compounds in hyphal exudates.

Sequencing of clone library inserted 16S rRNA gene fragments amplified from the DNA of the bacterial communities allowed us to identify several of the T-RFs that increased or decreased in abundance on hyphal-attached compared with the non-attached communities. Operational taxonomic identification of such T-RFs suggested Streptomyces and members of the Oxalobacteraceae family, specifically Duganella, Janthinobacterium and Massilia to be particularly abundant on hyphae. By contrast, Bacillus and Acinetobacter were less abundant or absent from the hyphal-attached bacterial communities.

Members from the Oxalobacteraceae family are commonly found in soil and rhizosphere (Green et al., 2007). Increasingly now, a number of reports have mentioned the possible interactions of this group of bacteria with (mycorrhizal) fungi. Oxalobacteraceae have been found to preferentially associate with mycorrhizal roots rather than with the roots of plant mutants that cannot form the AMF symbiosis (Offre et al., 2007, 2008). The similarity between the findings of these experiments, which were performed in natural soil, and our results that were obtained from a more controlled, but artificial system is a strong indication that we are looking at realistic interactions. In another recent study, a bacterial strain belonging to the Oxalobacteraceae family was isolated from mycorrhizal roots. This isolate promoted spore germination, hyphal growth and root colonisation of Glomus mosseae (Pivato et al., 2009). Furthermore, bacteria closely related to Janthinobacterium lividum have been isolated from AMF spores. These isolates showed strong antagonistic effects against several pathogenic fungi and were capable of phosphorus solubilisation (Cruz et al., 2008). Janthinobacterium sp. have also been isolated from ectomycorrhizal fungi and it was shown that these bacteria utilise fungal-derived sugars more readily than plant sugars (Izumi et al.,
2006). Moreover, Collimonas fungivorans, a mycophagous bacterium that is able to feed on living fungal hyphae, also belongs to the Oxalobacteraceae family (de Boer et al., 2004). Another point of evidence is that J. lividum can produce extracellular chitinases (Gleave et al., 1995), which is suggestive for its ability to degrade fungal cell walls. Janthinobacterium agaricidamnosum is a mushroom pathogen (Lincoln et al., 1999), while a J. lividum isolate with strong antifungal activity has also been isolated from salamander skin (Brucker et al., 2008). Taken together these data suggest that the Oxalobacteraceae may have particular importance for both beneficial and parasitic bacteria-fungi interactions.

In addition to the enriched abundance of Oxalobacteraceae members on hyphae, certain T-RFs also pointed to significantly more Streptomyces spp. attached to hyphae than remaining in liquid suspension. Given their filamentous form, we cannot be completely sure that the 'attachment' of Streptomyces to AMF hyphae is specific or an entanglement effect. However, it is noteworthy that Streptomyces was completely absent from the attached and non-attached fractions of the glass wool treatment. Streptomycetes are often found in soil and have also been found in association with roots or fungal hyphae. Different types of interactions have been reported for streptomycete-fungal interactions. In some cases streptomycetes inhibit fungal growth. Streptomyces griseoviridis for example, has been shown to depress mycorrhiza formation (Wyss et al., 1992). Other streptomycetes have a stimulatory effect on fungi, such as Streptomyces orientalis, which stimulates spore germination of some AMF (Tylka et al., 1991).

In contrast to streptomycetes and members of Oxalobacteraceae, T-RFs representative for Bacillus spp. were significantly less abundant or even absent in material recovered from hyphae. This is in marked contrast to what has been found earlier. Artursson and Jansson (2003) reported good attachment of pure cultures of $B$. cereus to hyphae of Glomus dussii. Our data did not specifically suggest presence of $B$. cereus in the communities isolated from soil and therefore we cannot refute or confirm their findings. It could indicate that there are species-specific differences in attachment abilities for Bacillus spp. As Artursson and Jansson used single pure culture attachment experiments, it is also possible that $B$. cereus can colonise hyphae when it is alone, but is a relatively bad coloniser in competition with other bacteria. Vitality of the hyphae might also have had a role. Toljander et al. (2006) found the same $B$. cereus strain to preferentially attach to nonvital hyphae of $G$. intraradices. In addition to $B$. cereus, also Paenibacillus spp. have been mentioned in a number of reports to attach to AMF hyphae, to stimulate mycorrhiza formation and to proliferate in the presence of hyphae (Budi et al., 1999; Mansfeld-Giese et al., 2002; Artursson 
and Jansson, 2003). In our experiments, we did find genetic signature evidence for Paenibacillus spp., notably from T-RF 303, but only in two cloned inserts. Interestingly, T-RF 303 was absent from bacterial communities attached to hyphae, which would suggest that Paenibacillus is not a good hyphal attacher. Again, however, it is important to realise that in our experimental conditions we separated attached bacteria from non-attached bacteria after $20 \mathrm{~h}$ of contact to hyphae and, therefore, it is possible that important 'slow-colonizers' under real-life soil conditions were not detected here. Finally, also T-RFs operationally defined as originating from Acinetobacter spp. were less abundant in hyphae-derived material. Despite a large amount of literature on Acinetobacter spp., no information is available on interaction or association with AMF, which would be in agreement with the observed lack of interaction in our data.

Given the difficulty to study AMF hyphae within their natural occurrence, it is not surprising that only a limited number of studies have attempted to investigate the role of bacteria in the hyphosphere. Some studies have investigated the ability of bacteria to attach to AMF hyphae, but only using pure and single cultures and sometimes with hyphae that were not connected to plant roots (Bianciotto et al., 1996, 2001; Toljander et al., 2006). Such studies may therefore have been biased towards less active AMF hyphae and non-competitive attachment. Others have investigated differences in bacterial community composition in soil in the presence or absence of AMF, in which case it is difficult to conclude which bacteria are attached to AMF (Andrade et al., 1998; Ravnskov et al., 1999; Mansfeld-Giese et al., 2002; Marschner and Baumann, 2003; Rillig et al., 2006). The system used here was successfully applied in the past to grow AMF but to guide their hyphae into compartments separately from the plant roots they are obligately attaching to. This permitted us to study bacterial attachment to AMF hyphae but without the interfering effects of plant root exudates. Bacteria were purified directly from agricultural soil without further cultivation, from which we believe that this approaches their natural activity and thus, their tendency to interact with the AMF hyphae. However, there are also some important limitations to our method and we do not claim to have achieved the complete picture of all bacteria that colonise AMF hyphae. The community approach allowed us to identify hyphal colonisers without a priori assumptions regarding which bacteria would be involved, but some steps in our experimental procedure, such as the extraction of bacteria from soil, the 20-h incubation and the PCR and cloning procedure, were probably selective for some bacterial groups, while it was also difficult to draw conclusions regarding lowly abundant bacteria. Exclusion of some bacterial groups is almost unavoidable in a controlled artificial system, and we can draw conclusions only regarding that part of the community that is amenable to our experimental procedure. The complete picture should arise by combining results of researchers using different experimental approaches.

In conclusion, we believe we have shown specific attachment to AMF hyphae by certain types of bacteria derived from agricultural soil. First, this indicates that the ability to attach to AMF hyphae is variable between different bacterial groups. Second, this specific attachment may be indicative for further colonisation and more complex types of interactions between bacteria and hyphae. Genetic signatures for several bacterial groups were obtained of which that for the family of Oxalobacteraceae is particularly interesting. Traces for this family were highly abundant on AMF hyphae after 20-h incubation, suggesting specific apt interactions with the fungi. This is in agreement with several recent reports, which pointed to the involvement of these bacteria in (mycorrhizal) fungal interactions. Further studies on their involvement in AMF-plant symbiosis seem therefore warranted.

\section{Acknowledgements}

We thank Hans-Rudolf Pfeiffer from the Faculty of Geosciences and the Environment at the University of Lausanne for chemical analysis of the soil that was used to extract bacteria. We also thank the reviewers for their useful comments on the paper. This research was supported by a FBM Interdisciplinary grant from the University of Lausanne.

\section{References}

Andrade G, Linderman RG, Bethlenfalvay GJ. (1998). Bacterial associations with the mycorrhizosphere and hyphosphere of the arbuscular mycorrhizal fungus Glomus mosseae. Plant Soil 202: 79-87.

Artursson V, Jansson JK. (2003). Use of bromodeoxyuridine immunocapture to identify active bacteria associated with arbuscular mycorrhizal hyphae. Appl Environ Microbiol 69: 6208-6215.

Azcon-Aguilar C, Barea JM. (1996). Arbuscular mycorrhizas and biological control of soil-borne plant pathogens-an overview of the mechanisms involved. Mycorrhiza 6: 457-464.

Becard G, Fortin JA. (1988). Early events of vesicular arbuscular mycorrhiza formation on $\mathrm{Ri}$ T-DNA transformed roots. New Phytol 108: 211-218.

Bianciotto V, Andreotti S, Balestrini R, Bonfante P, Perotto S. (2001). Mucoid mutants of the biocontrol strain Pseudomonas fluorescens CHA0 show increased ability in biofilm formation on mycorrhizal and nonmycorrhizal carrot roots. Mol Plant Microbe Interact 14: 255-260.

Bianciotto V, Minerdi D, Perotto S, Bonfante P. (1996). Cellular interactions between arbuscular mycorrhizal fungi and rhizosphere bacteria. Protoplasma 193: 123-131. 
Bonfante P, Anca IA. (2009). Plants, mycorrhizal fungi, and bacteria: a network of interactions. Annu Rev Microbiol 63: 363-383.

Borowicz VA. (2001). Do arbuscular mycorrhizal fungi alter plant-pathogen relations? Ecology 82: 3057-3068.

Brucker RM, Harris RN, Schwantes CR, Gallaher TN, Flaherty DC, Lam BA et al. (2008). Amphibian chemical defense: antifungal metabolites of the microsymbiont Janthinobacterium lividum on the salamander Plethodon cinereus. J Chem Ecol 34: 1422-1429.

Budi SW, van Tuinen D, Martinotti G, Gianinazzi S. (1999). Isolation from the Sorghum bicolor mycorrhizosphere of a bacterium compatible with arbuscular mycorrhiza development and antagonistic towards soilborne fungal pathogens. Appl Environ Microbiol 65: $5148-5150$.

Bürgmann H, Pesaro M, Widmer F, Zeyer J. (2001). A strategy for optimizing quality and quantity of DNA extracted from soil. J Microbiol Methods 45: 7-21.

Cruz AF, Horii S, Ochiai S, Yasuda A, Ishii T. (2008). Isolation and analysis of bacteria associated with spores of Gigaspora margarita. J Appl Microbiol 104: 1711-1717.

Davies FT, Potter JR, Linderman RG. (1993). Drought resistance of mycorrhizal pepper plants independent of leaf $\mathrm{P}$ concentration-response in gas exchange and water relations. Physiol Plant 87: 45-53.

de Boer W, Leveau JHJ, Kowalchuk GA, Gunnewiek P, Abeln ECA, Figge MJ et al. (2004). Collimonas fungivorans gen. nov., sp nov., a chitinolytic soil bacterium with the ability to grow on living fungal hyphae. Int J Syst Evol Microbiol 54: 857-864.

Declerck S, Cranenbrouck S, Dalpe Y, Seguin S, Grandmougin-Ferjani A, Fontaine J et al. (2000). Glomus proliferum sp nov.: a description based on morphological, biochemical, molecular and monoxenic cultivation data. Mycologia 92: 1178-1187.

Filion M, St-Arnaud M, Fortin JA. (1999). Direct interaction between the arbuscular mycorrhizal fungus Glomus intraradices and different rhizosphere microorganisms. New Phytol 141: 525-533.

Frey-Klett P, Garbaye J, Tarkka M. (2007). The mycorrhiza helper bacteria revisited. New Phytol 176: 22-36.

Garbaye J. (1994). Helper bacteria: a new dimension to the mycorrhizal symbiosis. New Phytol 128: 197-210.

Gleave AP, Taylor RK, Morris BAM, Greenwood DR. (1995). Cloning and sequencing of a gene encoding the 69-kDa extracellular chitinase of Janthinobacterium lividum. FEMS Microbiol Ecol 131: 279-288.

Green SJ, Michel FC, Hadar Y, Minz D. (2007). Contrasting patterns of seed and root colonization by bacteria from the genus Chryseobacterium and from the family Oxalobacteraceae. ISME J 1: 291-299.

Izumi H, Anderson IC, Alexander IJ, Killham K, Moore ERB. (2006). Endobacteria in some ectomycorrhiza of Scots pine (Pinus sylvestris). FEMS Microbiol Ecol 56: 34-43.

Johansson JF, Paul LR, Finlay RD. (2004). Microbial interactions in the mycorrhizosphere and their significance for sustainable agriculture. FEMS Microbiol Ecol 48: 1-13.

Koch AM, Kuhn G, Fontanillas P, Fumagalli L, Goudet J, Sanders IR. (2004). High genetic variability and low local diversity in a population of arbuscular mycorrhizal fungi. PNAS 101: 2369-2374.

Lane DJ. (1991). 16S/23S rRNA sequencing. In: Stackebrandt E, Goodfellow M (eds). Nucleic Acid
Techniques in Bacterial Systematics. John Wiley \& Sons: New York pp 115-175.

Lincoln SP, Fermor TR, Tindall BJ. (1999). Janthinobacterium agaricidamnosum sp nov., a soft rot pathogen of Agaricus bisporus. Int J Syst Bacteriol 49: 1577-1589.

Mansfeld-Giese K, Larsen J, Bodker L. (2002). Bacterial populations associated with mycelium of the arbuscular mycorrhizal fungus Glomus intraradices. FEMS Microbiol Ecol 41: 133-140.

Marschner P, Baumann K. (2003). Changes in bacterial community structure induced by mycorrhizal colonisation in split-root maize. Plant Soil 251: 279-289.

Mayo K, Davis RE, Motta J. (1986). Stimulation of germination of spores of Glomus versiforme by spore-associated bacteria. Mycologia 78: 426-431.

Muyzer G, de Waal EC, Uitterlinden AG. (1993). Profiling of complex microbial-populations by denaturing gradient gel-electrophoresis analysis of polymerase chain reaction-amplified genes-coding for $16 \mathrm{~S}$ ribosomal-RNA. Appl Environ Microbiol 59: 695-700.

Newsham KK, Fitter AH, Watkinson AR. (1995). Multi-functionality and biodiversity in arbuscular mycorrhizas. Trends Ecol Evol 10: 407-411.

Offre P, Pivato B, Mazurier S, Siblot S, Berta G, Lemanceau $P$ et al. (2008). Microdiversity of Burkholderiales associated with mycorrhizal and nonmycorrhizal roots of Medicago truncatula. FEMS Microbiol Ecol 65: 180-192.

Offre P, Pivato B, Siblot S, Gamalero E, Corberand T, Lemanceau P et al. (2007). Identification of bacterial groups preferentially associated with mycorrhizal roots of Medicago truncatula. Appl Environ Microbiol 73: 913-921.

Pivato B, Offre P, Marchelli S, Barbonaglia B, Mougel C, Lemanceau $\mathrm{P}$ et al. (2009). Bacterial effects on arbuscular mycorrhizal fungi and mycorrhiza development as influenced by the bacteria, fungi, and host plant. Mycorrhiza 19: 81-90.

Ravnskov S, Nybroe O, Jakobsen I. (1999). Influence of an arbuscular mycorrhizal fungus on Pseudomonas fluorescens DF57 in rhizosphere and hyphosphere soil. New Phytol 142: 113-122.

Requena N, Jimenez I, Toro M, Barea JM. (1997). Interactions between plant-growth-promoting rhizobacteria (PGPR), arbuscular mycorrhizal fungi and Rhizobium spp. in the rhizosphere of Anthyllis cytisoides, a model legume for revegetation in mediterranean semi-arid ecosystems. New Phytol 136: 667-677.

Rillig MC, Mummey DL, Ramsey PW, Klironomos JN, Gannon JE. (2006). Phylogeny of arbuscular mycorrhizal fungi predicts community composition of symbiosis-associated bacteria. FEMS Microbiol Ecol 57: 389-395.

Smith SE, Read DJ. (1997). Mycorrhizal Symbiosis, 2nd edn. Academic Press: London.

St-Arnaud M, Hamel C, Vimard B, Caron M, Fortin JA. (1996). Enhanced hyphal growth and spore production of the arbuscular mycorrhizal fungus Glomus intraradices in an in vitro system in the absence of host roots. Mycol Res 100: 328-332.

Toljander JF, Artursson V, Paul LR, Jansson JK, Finlay RD. (2006). Attachment of different soil bacteria to arbuscular mycorrhizal fungal extraradical hyphae is determined by hyphal vitality and fungal species. FEMS Microbiol Ecol 254: 34-40.

Toljander JF, Lindahl BD, Paul LR, Elfstrand M, Finlay RD. (2007). Influence of arbuscular mycorrhizal mycelial 
exudates on soil bacterial growth and community structure. FEMS Microbiol Ecol 61: 295-304.

Trappe JM. (1987). Phylogenetic and ecological aspects of mycotrophy in the angiosperms from an evolutionary standpoint. In: Safir GR (eds). Ecophysiology of VA Mycorrhizal Plants. CRC Press: Boca Raton, pp 5-25.

Tylka GL, Hussey RS, Roncadori RW. (1991). Axenic germination of vesicular-arbuscular mycorrhizal fungi - effects of selected Streptomyces-species. Phytopathology 81: 754-759.

Wamberg C, Christensen S, Jakobsen I, Muller AK, Sørensen SJ. (2003). The mycorrhizal fungus (Glomus intraradices) affects microbial activity in the rhizosphere of pea plants (Pisum sativum). Soil Biol Biochem 35: 1349-1357.

Wang Q, Garrity GM, Tiedje JM, Cole JR. (2007). Naive Bayesian classifier for rapid assignment of rRNA sequences into the new bacterial taxonomy. Appl Environ Microbiol 73: 5261-5267.

Weller DM. (2007). Pseudomonas biocontrol agents of soilborne pathogens: looking back over 30 years. Phytopathology 97: 250-256.

Whipps JM. (2001). Microbial interactions and biocontrol in the rhizosphere. J Exp Bot 52: 487-511.

Wyss P, Boller T, Wiemken A. (1992). Testing the effect of biological control agents on the formation of vesicular arbuscular mycorrhiza. Plant Soil 147: 159-162.

Xavier LJC, Germida JJ. (2002). Response of lentil under controlled conditions to co-inoculation with arbuscular mycorrhizal fungi and rhizobia varying in efficacy. Soil Biol Biochem 34: 181-188.

Xavier LJC, Germida JJ. (2003). Bacteria associated with Glomus clarum spores influence mycorrhizal activity. Soil Biol Biochem 35: 471-478.

Supplementary Information accompanies the paper on The ISME Journal website (http://www.nature.com/ismej) 